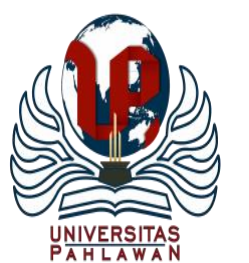

Jurnal Abdidas Volume 2 Nomor 6 Tahun 2021 Halaman 1362 - 1367

JURNAL ABDIDAS

http://abdidas.org/index.php/abdidas

\title{
Sosialisasi Penggunaan Metode Konstruktivisme Terhadap Kemampuan Menulis Karangan Narasi di Sekolah SMP NU Tebat Jaya
}

\author{
Sugiarti ${ }^{1 \bowtie}$, Kesi $^{2}$ \\ Universitas Nurul Huda, Indonesia, ${ }^{1,2}$ \\ E-mail : giarti@stkipnurulhuda.ac.id ${ }^{1} \underline{\text { kesi@gmail.com }}^{2}$
}

\begin{abstract}
Abstrak
Menulis adalah salah satu keterampilan berbahasa yang digunakan untuk berkomunikasi tanpa tatap muka dengan orang lain. Keterampilan menulis narasi merupakan salah satu aspek kemampuan berbahasa yang diajarkan dalam mata pelajaran bahasa Indonesia. Kemampuan menulis narasi siswa kelas VII SMP NU Tebat Jaya masih rendah. Oleh karena itu, perlu adanya tindakan atau solusi dalam meningkatkan keterampilan menulis. Penelitian ini bertujuan untuk meningkatkan keterampilan menulis narasi menggunakan metode konstruktivisme di SMP NU Tebat Jaya. Metode berarti cara. Dalam pemakaian umum metode diartikan sebagai suatu cara atau prosedur yang dipakai untuk mencapai tujuan tertentu. Dengan menggunakan metode ini diharapkan dapat peningkatan kemampuan siswa dalam menulis karangan narasi. Untuk membangun pengetahuan siswa dalam proses belajar mengajar berdasarkan pengalaman yang telah dimiliki siswa sebelumnya. Disini guru dapat memanfaatkan pengalaman siswa untuk dijadikan ide dalam menulis karangan narasi. Karangan narasi merupakan salah satu karangan yang dapat dijadikan alat untuk menyampaikan pengetahuan atau informasi kepada orang lain. serta dapat menghubungkan pelajaran yang diperoleh di sekolah dengan kehidupan sehari-hari dari pengalaman yang pernah dialaminya. Selain itu siswa juga dapat menggali ide-ide yang ada dalam diri siswa sehingga tercipta peroses belajar mengajar yang menyenangkan dan tidak membosankan.Jadi metode konstruktivisme diterapkan dalam pembelajaran menulis karangan narasi supaya kemampuan siswa dalam menulis karangan narasi lebih baik lagi.
\end{abstract}

Kata kunci: metode konstruktivisme, kemampuan, menulis karangan narasi

\begin{abstract}
Writing is one of the language skills used to communicate without face to face with other people. Narrative writing skills are one aspect of language skills taught in Indonesian subjects. The ability to write narratives for seventh grade students of SMP NU Tebat Jaya is still low. Therefore, it is necessary to take action or solutions in improving writing skills. This study aims to improve narrative writing skills using the constructivism method at SMP NU Tebat Jaya. Method means way. In general use, the method is defined as a method or procedure used to achieve certain goals. By using this method, it is expected to increase students' ability in writing narrative essays. To build students' knowledge in the teaching and learning process based on the experiences that students have had before. Here the teacher can take advantage of students' experiences to be used as ideas in writing narrative essays. Narrative essay is one of the essays that can be used as a tool to convey knowledge or information to others. and can connect the lessons learned at school with everyday life from the experiences they have experienced. In addition, students can also explore the ideas that exist in students so that the teaching and learning process is fun and not boring. So the constructivism method is applied in learning to write narrative essays so that students' abilities in writing narrative essays are even better.
\end{abstract}

Keywords: constructivism method, ability, writing narrative essay

Copyright (c) 2021 Sugiarti, Kesi

$\triangle$ Corresponding author

Address : Universitas Nurul Huda

Email : giarti@stkipnurulhuda.ac.id

DOI : https://doi.org/10.31004/abdidas.v2i6.478

ISSN 2721-9224 (Media Cetak)

ISSN 2721- 9216 (Media Online) 
1363 Sosialisasi Penggunaan Metode Konstruktivisme Terhadap Kemampuan Menulis Karangan Narasi di Sekolah SMP NU Tebat Jaya - Sugiarti, Kesi

DOI: https://doi.org/10.31004/abdidas.v2i6.478

\section{PENDAHULUAN}

Menulis merupakan suatu keterampilan berbahasa yang harus dikuasai oleh siswa. Menulis adalah salah satu dari 4 keterampilan berbahasa yaitu keterampilan berbicara, menyimak, membaca dan menulis. Keterampilan menulis merupakan suatu kegiatan yang produktif dan ekspresif (Tarigan, 2008). Menulis merupakan keterampilan memanfaatkan struktur bahasa dan kosa kata (Sismulyasih, 2015). Menulis merupakan salah satu aspek keterampilan berbahasa yang sangat rumit (Mardiyah, 2016). Dapat disimpulkan bahwa menulis merupakan aspek keterampilan yang produktif dan efektif). Dengan menulis siswaakan dapat menuangkan ide dan gagasannya kedalam bentuk tulisan atau karangan.Peran aktif siswa dituntut untuk melakukan suatu tindakan yang menghasilkan dalam suatu keterampilan menulis, karena menulis juga merupakan suatu bentuk sarana untuk berkomunikasi. Komunikasi adalah saling berhubungannya antara komunikator dan resipiens, dimana komunikator menyampaikan suatu pesan kepada resipiens melalui medium untuk mencapai suatu tujuan tertentu. Menulis karangan narasi merupakan salah satu hal yang sangat produktif.

Menurut (Nurudin, 2007) "Narasi adalah bentuk tulisan yang berusaha menciptakan, mengisahkan, merangkaikan tindak-tanduk perbuatan manusia dalam sebuah peristiwa secara kronologis atau yang berlangsung dalam satu kesatuan waktu tertentu." Narasi adalah tulisan yang tujuanya menceritakan kronologis peristiwa kehidupan manusia (Semi, 2008). Menulis karangan narasi sebagai salah satu kemampuan menulis kreatif yang menuntut penulisnya untuk berfikir kreatif dan mengembangkan imajinasinya, sehingga penulis dituntut untuk memiliki kreatifitas yang baik, dan berasal dari dirinya sendiri. Melalui kegiatan menulis karangan narasi, siswa diharapkan mampu memiliki kemampuan dalam menulis karangan narasi dengan baik. Namun dalam kegiatan menulis karangan narasi siswa mengalami kesulitan dalam pemilihan kata, kurangnya pengetahuan, keterkaitan cerita, dan lain-lain.

Menulis adalah salah satu keterampilan berbahasa yang digunakan untuk berkomunikasi tanpa tatap muka dengan orang lain. Keterampilan menulis narasi merupakan salah satu aspek kemampuan berbahasa yang diajarkan dalam mata pelajaran bahasa Indonesia. Kemampuan menulis narasi siswa kelas VII SMP NU Tebat Jaya masih rendah. Oleh karena itu, perlu adanya tindakan atau solusi dalam meningkatkan keterampilan menulis. Penelitian ini bertujuan untuk meningkatkan keterampilan menulis narasi menggunakan metode konstruktivisme di SMP NU Tebat Jaya.

Konstruktivisme merupakan landasan berpikir (filosofi) pembelajaran konstruktivisme, yaitu bahwa pengetahuan dibangun oleh manusia sedikit demi sedikit, yang hasilnya diperluas melalui konteks yang terbatas (sempit) dan tidak sekonyong-konyong. Konstruktivisme adalah suatu upaya membangun tata susunan hidup yang berbudaya modern (Suparlan, 2019). (Suprijono, 2009) mengemukakan Konstruktivisme membutuhkan kemampuan mengingat dan mengungkapkan kembali pengalaman, kemampuan 
1364 Sosialisasi Penggunaan Metode Konstruktivisme Terhadap Kemampuan Menulis Karangan Narasi di Sekolah SMP NU Tebat Jaya - Sugiarti, Kesi

DOI: https://doi.org/10.31004/abdidas.v2i6.478

membandingkan, kemampuan mengambil kebutusan dan kemampuan lebih menyukai yang satu daripada yang lain. Konstruktivisme adalah keberhasilan belajar bukan hanya tergantung pada lingkungan atau kondisi belajar melainkan pada pengetahuan awal siswa (Teti, Novi Risqi dan Kusumo, 2013). Konstruktivisme adalah suatu filsafat yang menganggap pengetahuan adalah hasil dari kontruksi manusia itu sendiri (Rangkuti, 2014). Jadi Konstruktivisme adalah membutuhkan kemampuan mengingat dan mengungkapkan pengalaman kembali.

\section{METODE}

Sosialisasi penggunaan metode konstrukvisme terhadap kemampuan menulis karangan narasi di sekolah SMP NU Tebat Jaya dilaksanakan pada tanggal 18 Oktober 2021 di sekolah SMP NU Tebat Jaya. Untuk membangun pengetahuan siswa dalam proses belajar mengajar berdasarkan pengalaman yang telah dimiliki siswa. Selain itu siswa juga dapat menggali ide-ide yang ada dalam diri siswa sehingga tercipta peroses belajar mengajar yang menyenangkan dan tidak membosankan. Sedangkan metode konstruktivisme diterapkan dalam pembelajaran menulis karangan narasi supaya kemampuan siswa dalam menulis karangan narasi lebih baik lagi.

Pada kegiatan ini, program yang paling penting adalah memberikan sosialisasi tentang penggunaan metode konstruktivisme terhadap kemampuan menulis karangan narasi di sekolah SMP NU Tebat Jaya. Sosialisasi dilakukan dengan metode ceramah. Kegiatan terakhir yang dilakaukan adalah evaluasi hasil.

\section{HASIL DAN PEMBAHASAN}

Penggunaan metode konstruktivisme terhadap kemampuan menulis karangan Narasi Di Sekolah SMP NU Tebat Jaya, siswa akan berpartisipasi secara aktif dalam proses pembelajaran, siswa dapat mengembangkan kemampuan belajar mandiri, siswa mampu mengembangkan pengetahuannya sendiri, serta guru sebagai fasilitator, mediator dan manajer. Hasil pelaksanaan kegiatan bahwa metode Konstruktivisme merupakan komponen dari strategi contextual teaching and learning (CTL). Bahwa pengetahuan dibangun manusia sedikit demi sedikit, hasilnya diperluas melalui konteks yang terbatas (sempit).

Ilmu pengetahuan tidak boleh dipindahkan kepada pesertadidik dalam bentuk yang serba jadi melalui program pengajaran guru. Jadi metode konstruktivisme adalah suatu metode yang menuntut siswa untuk membangun sendiri pengetahuan mereka melalui keterlibatan aktif dalam proses belajar mengajar berdasarkan pengalaman yang telah dimiliki siswa sebelumnya. Disini guru dapat memanfaatkan pengalaman siswa untuk dijadikan ide dalam menulis karangan narasi. Karangan narasi merupakan salah satu karangan yang dapat dijadikan alat untuk menyampaikan pengetahuan atau informasi kepada orang lain. Narasi menambah ilmu pengetahuan.

$$
\text { Sedangkan penerapan metode }
$$
konstruktivisme sebagai cara pemecahan masalah yaitu penerapan metode konstruktivisme dalam pembelajaran menulis karangan narasi pada siswa telah berhasil diterapkan. Hal ini dapat dibuktikan dengan hasil kerja siswa dalam menulis karangan 
1365 Sosialisasi Penggunaan Metode Konstruktivisme Terhadap Kemampuan Menulis Karangan Narasi di Sekolah SMP NU Tebat Jaya - Sugiarti, Kesi

DOI: https://doi.org/10.31004/abdidas.v2i6.478

narasi dalam bentuk paragraf yang baik. Karena Metode konstruktivisme sangat efektif digunakan dalam pembelajaran menulis karangan narasi, sebab dengan metode konstruktivisme siswa mampu menulis karangan narasi dengan suasana yang menyenangkan dan tidak monoton.

Narasi merupakan penambahan ilmu karena ada pengetahuan melalui jalan ceritanya, bagaimana peristiwa itu berlangsung. Narasi lebih menekankan pada jalannya peristiwa, hasil dari kejadian merupakan bidang utama sebuah narasi meskipun itu berupa fakta maupun fiksi. cerita, bagaimana peristiwa itu berlangsung. Karena lebih menekankan jalannya peristiwa, reproduksi masa silam merupakan bidang utama sebuah narasi. Seorang dapat menginformasikan sesuatu kejadian atau peristiwa kepada orang lain dengan latar belakang kejadian yang nyata atau rekaan.

Menulis karangan narasi, penulis dituntut mamapu menbedakan antara narasi dan deskripsi. Narasi mempunyai kesamaan dengan deskripsi yang membedakan adalah narasi mengandung imajinasi dan peristiwa atau pengalaman lebih ditekankan pada urutan kronologis. Deskripsi unsur imajiasi terbatas pada penekanan organisasi penyampaian pada susunan ruang sebagaimana yang diamati, dirasakan, dan dengar. Oleh karena itu, penulis perlu memperhatikan unsur latar, baik unsur waktu maupun unsur tempat. Dengan kata lain, pengertian narasi itu mencakup dua unsur, yaitu perbuatan dan tindakan yang terjadi dalam suatu rangkaian waktu.

Metode konstruktivisme adalah suatu metode yang menuntut siswa untuk membangun sendiri pengetahuan mereka melalui keterlibatan aktif dalam proses belajar mengajar berdasarkan pengalaman yang telah dimiliki siswa sebelumnya. Disini guru dapat memanfaatkan pengalaman siswa untuk dijadikan ide dalam menulis karangan narasi. Pada dasarnya setiap siswa mempunyai banyak pengalaman yang dapat dijadikan landasan untuk siswa dalam menulis karangan narasi. Pengalamanpun bermacam-macam ada yang menggembirakan dan menyedihkan. Namun tidak semua pengalaman dapatlah kita ingat atau bisa dikatakan terlupakan. Banyak cara yang dapat dilakukan untuk mengingat atau membangkitkan pengalaman yang telah terlupakan misalnya dengan gambar, lagu, berdiskusi dengan teman, melihat kejadian-kejadian disekitar dan lain-lain. Hal tersebut akan membangkitkan ingatan kita terhadap pengalaman yang telah kita lalui. Untuk pembelajaran didalam kelas, guru dapat memanfaatkan hal-hal tersebut untuk membangkitkan ingatan siswa akan pengalaman untuk dijadikan suatu karangan.

Dalam hal ini guru harus pandai dalam memancing atau merangsang siswa agar dapat mengingat kembali pengalaman yang menarik untuk dijadikan suatu karangan. Adapun langkahlangkah dalam menulis karangan narasi dengan menggunakan metode konstruktivisme, diantaranya.

a. Tahap prapenulisan, yang meliputi langkahlangkah berikut:

1. Menentukan ide. Ide disini didapat dari mengingat pengalaman yang menarik yang telah dialami oleh siswa.

2. Menyusun kerangka karangan. Dengan membuat kerangka karangan akan dapat 
1366 Sosialisasi Penggunaan Metode Konstruktivisme Terhadap Kemampuan Menulis Karangan Narasi di Sekolah SMP NU Tebat Jaya - Sugiarti, Kesi

DOI: https://doi.org/10.31004/abdidas.v2i6.478

memudahkan siswa dalam dalam menulis, dan juga memudahkan dalam merinci pengalaman yang akan dijadikan karangan.

b. Tahap penulisan, mengembangkan kerangka, menjadi karangan narasi.

c. Tahap pascapenulisan, membaca kembali dam mengoreksi karangan yang telah dibuat.

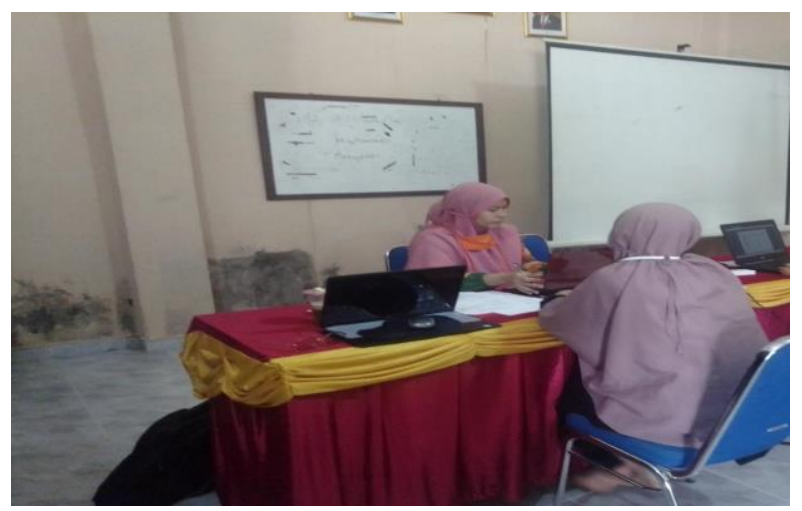

Gambar 1. Foto Persiapan PKM

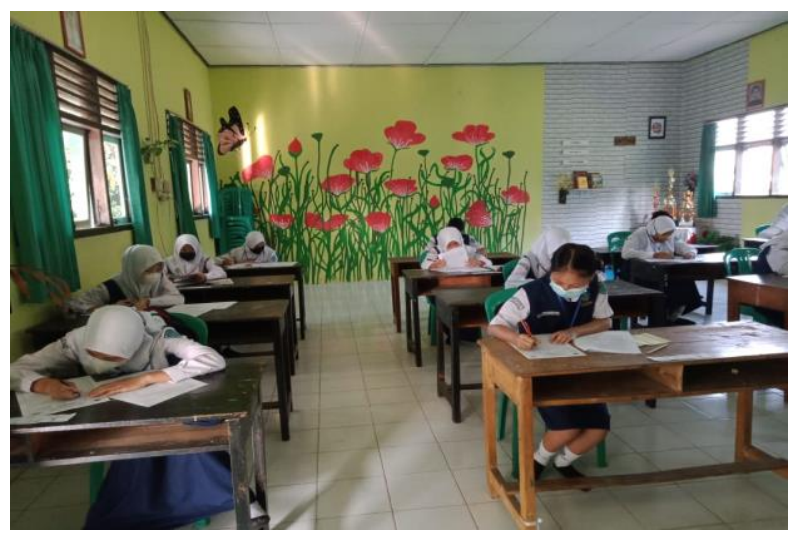

Gambar 2. Menulis Karangan Narasi

Sedangkan dampak dari penggunaan metode konstruktivisme terhadap kemampuan menulis karangan Narasi Di Sekolah SMP NU Tebat Jaya yaitu: 1) Konstruktivis menanamkan agar siswa membangun pengetahuannya sendiri. 2) pengetahuan terdapat dari siswa sendiri, sehingga hasil konstruksi siswa tidak cocok dengan hasil konstruksi para ilmuan. Manfaat penggunaan metode konstruktivisme terhadap kemampuan menulis karangan Narasi Di Sekolah SMP NU Tebat Jaya yaitu Siswa dapat lebih paham karena terlibat secara langsung dalam membina pengetahuan baru.

\section{SIMPULAN}

Metode konstruktivisme sangat efektif digunakan dalam pembelajaran menulis karangan narasi, karena dengan metode konstruktivisme siswa mampu menulis karangan narasi dengan suasana yang menyenangkan dan tidak monoton. Narasi merupakan penambahan ilmu karena ada pengetahuan melalui jalan ceritanya, bagaimana peristiwa itu berlangsung. Karena pada narasi lebih menekankan pada jalannya peristiwa, hasil dari kejadian merupakan bidang utama sebuah narasi meskipun itu berupa fakta maupun fiksi. Dalam narasi mengandung imajinasi dan peristiwa atau pengalaman lebih ditekankan pada urutan kronologis.

\section{UCAPAN TERIMA KASIH}

Ucapan terima kasih ditujukan kepada rektor Universitas Nurul Huda, ketua LPPM, dan TIM penelitian pengabdian yang telah berupaya sekuat tenaga demi kesuksesan pengabdian ini.

\section{DAFTAR PUSTAKA}

Maesaroh, S. (2013). Peranan Metode Pembelajaran terhadap Minat Baca dan Prestasi Belajara Pendidikan Agama Islam. Pendidikan.

Mardiyah. (2016). Keterampilan Menulis Bahasa Indonesia Melalui Kemampuan 
1367 Sosialisasi Penggunaan Metode Konstruktivisme Terhadap Kemampuan Menulis Karangan Narasi di Sekolah SMP NU Tebat Jaya - Sugiarti, Kesi

DOI: https://doi.org/10.31004/abdidas.v2i6.478

Mengembangkan Struktur Paragraf.

Pendidikan Dan Pembelajaran Bahasa, 3.

Nurudin. (2007). Pengantar Kominukasi Massa. Raja Gafindi Persada.

Rangkuti, A. N. (2014). Konstruktivisme dan Pembelajaran Matematika. Darul Ilmi, 2.

Semi, A. (2008). Dasar-dasar Keterampilan Menulis. Angkasa.

Sismulyasih, N. (2015). Peningkatan Keterampilan Menulis Manuskrip Jurnal Ilmiah menggunakan Strategi Syinergetic Teaching pada Mahasiswa pada Mahasiswa. Primary, 4.

Suparlan. (2019). Teori Konstruktivisme dalam Pembelajaran. Keislaman Dan Ilmu Pendidikan, 1 .

Suprijono, A. (2009). Cooperative lEarning. Pustaka Pelajar.

Tarigan, H. G. (2008). Menulis. Angkasa.

Teti, Novi Risqi dan Kusumo, E. (2013). Penerapan Model Pembelajaran Konstruktivisme Berbantuan Concept MAP untuk Meningkatkan Hasil Belajar Kimia pada Siswa SMA. Inovasi Pendidikan Kimia, 7. 